\title{
ASSESMENT OF SURFACE WATER QUALITY IN THE VICINITY OF AN INDUSTRIAL AREA NEAR VILLAGE DATAV OF RAIGAD, MAHARASHTRA
}

\author{
S. M. Tandale ${ }^{1}$, H. A. Mujawar ${ }^{2}$ \\ ${ }^{1}$ Research Scholar, Department of Chemistry, Dr. Babasaheb Ambedkar Technological University, Lonere, Raigad, \\ Maharashtra \\ ${ }^{2}$ Head, Department of Chemistry, Dr. Babasaheb Ambedkar Technological University, Lonere, Raigad, Maharashtra
}

\begin{abstract}
Water quality parameters of four streams (Nala) in the Dhatav Industrial area in Raigad District of Maharashtra were assessed during the period of December 2009 to November 2010. These Nala's joins to Kundalika river which flows across the Roha city and nearby villages. The seasonal variation in the quality of water was observed. The depletion of DO is more in rainy season than the summer season. The COD of Nala -1 was higher in rainy season. Turbidity of samples was comparatively low however some of the samples were colored. Hardness of the samples was in the range from 32 to 420 ppm. The pollution of Kundalika river water mostly related with the quantity of pollutants released through these Nala. Hence, the Nala - 1 is comparatively adding more waste water in river.
\end{abstract}

Keywords: $C O D$, Water quality index, DO, TDS, Surface water.

\section{INTRODUCTION}

Water is the nature's most wonderful, useful, abundant and most precious gift to human kind. Water contains essential elements for existence of human beings, animals and plants. Rivers are life lines of the people and restoring the health of the rivers is immensely required, which have become polluted. Human and ecological use of water depends upon water quality [8].

Kundalika River is the one of the rivers which is polluted due to nearby chemical industries in the Konkan region of Maharashtra. This river supplies water to Roha town, Roha industrial area and villages located on the river sides. Pollution of river originates due to leakages of drainage network from industrial and municipal waste water, manure discharge, agricultural drainage, etc.

The present study is undertaken to assess the quality of surface water of streams of industrial belt. This will be helpful to understand the effect of industrial effluent on the health of river water which in turn affects the human ecology, material.. Pimple [5] had carried out research on Taloja MIDC area and found to be highly polluted water. Indira Gupta et al[6].

\section{MATERIALS AND METHODS}

The water samples were collected from the Kundalika River and nala, which emerges into Kundalika River of the Roha MIDC in Kokan region. The water samples were collected during the period of December 2009 to November 2010, for one year, twice in the season. The water samples were analyzed for different water quality parameters according to standard methods prescribed by APHA [1] and a manual on water and waste water analysis by National Environmental Engineering Institute (NEERI), Nagpur [2].

\subsection{Study Area}

The study area is located at the bank of the Kundalika river. It is about seventy kilometers from Panvel. The area is located around Roha town. It is inbetween Kolad and Roha.[9], Khan, M. M. et. al. [7], have assessed the suitability of water quality of river Shinta.

Table -1: Description of sampling locations is as above Standards and Weightage

\begin{tabular}{|l|l|l|}
\hline $\begin{array}{l}\text { Sr. } \\
\text { No. }\end{array}$ & $\begin{array}{l}\text { Sampling } \\
\text { Location }\end{array}$ & Description of sampling Location \\
\hline 01 & N1 & Near Dhatav MIDC stop, it is Nala \\
\hline 02 & N2 & $\begin{array}{l}\text { Towards Roha 6km away from Mumbai Goa } \\
\text { highway }\end{array}$ \\
\hline 03 & N3 & It is below the bridge of Ganga river \\
\hline 04 & N4 & Situated at the Roha Ghat of Kundalika river \\
\hline
\end{tabular}


In the formation of water quality index, the importance of various parameters depends on the intended use of water. The authors consider the standards recommended for drinking water for human consumption. The standards for drinking water [3] recommended by the Indian Council of Medical Research (ICMR) are given in the second column of the Table 1 for parameters consider by the authors.

Table-2: I.C.M.R. Standards and Unit Weights of Water Quality Parameters (All values except $\mathrm{P}^{\mathrm{H}}$ and turbidity are in $\mathrm{mg} / \mathrm{L}$ )

\begin{tabular}{|l|l|l|}
\hline $\begin{array}{l}\text { Water Quality } \\
\text { Parameters Pi }\end{array}$ & $\begin{array}{l}\text { ICMR standards } \\
\mathrm{Si}\end{array}$ & $\begin{array}{l}\text { Unit weight } \\
\mathrm{Wi}\end{array}$ \\
\hline Dissolved Oxygen & 05 & 0.2000 \\
\hline BOD & 05 & 0.2000 \\
\hline Chlorides & 250 & 0.004 \\
\hline Alkalinity & 120 & 0.0083 \\
\hline Total Hardness & 300 & 0.0033 \\
\hline Turbidity & 05 & 0.2000 \\
\hline PH & $6.5-8.5$ & 0.1000 \\
\hline
\end{tabular}

The weights for various water quality parameters are assumed to be inversely proportional to the recommended standards for the corresponding parameters.

$$
\mathrm{W}_{\mathrm{i}}=\mathrm{K} / \mathrm{S}
$$

Where $\mathrm{Wi}=$ unit weight for the $\mathrm{i}^{\text {th }}$ parameter $\mathrm{P}_{\mathrm{i}}(1,2, \ldots \ldots .7)$ and $\mathrm{K}=$ constant of proportionality. For the sake of simplicity we assume that $\mathrm{K}=1$.

The unit weights $\mathrm{w}_{\mathrm{i}}$, obtained from Eq. (1.1) with $\mathrm{K}=1$, are shown in the third column of Table 2. For PH, we have assumed the same unit weights as that of chlorides, viz. 0.0040 .

\section{RESULTS AND DISCUSSION}

\subsection{Dissolved Oxygen}

DO value is lowest in the month of September (0.3 ppm) because during monsoon the large amount of waste is disposed in the flow of water so that it will drain away. The highest concentration of DO is in the month of November (6.7 ppm).

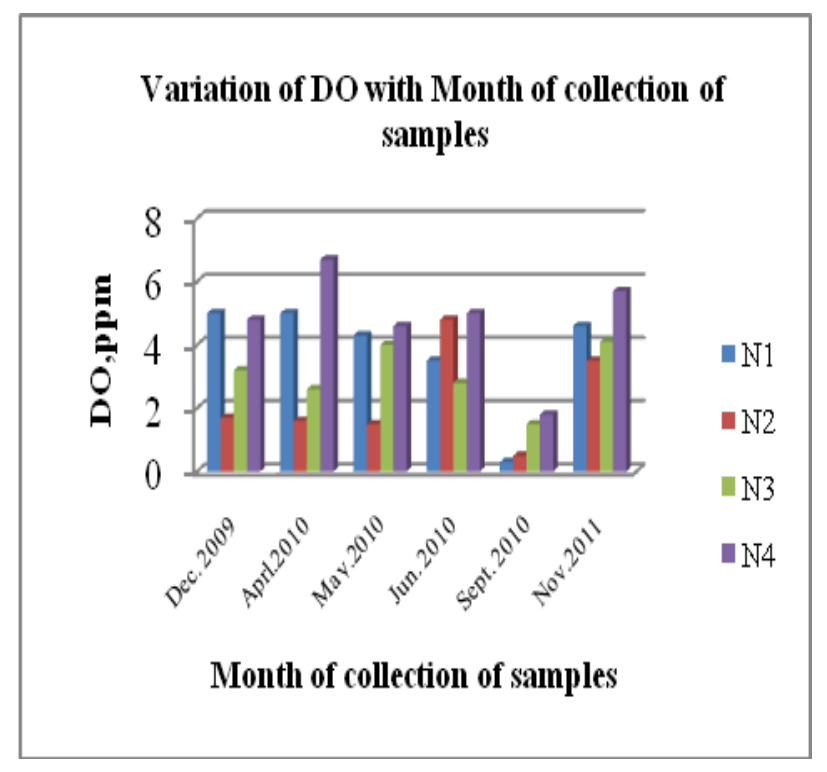

Fig-1: Variation of Dissolved Oxygen with month of sample collection

\subsection{Biological Oxygen Demand}

The BOD values ranges from $4 \mathrm{ppm}$ to $30.48 \mathrm{ppm}$. The highest value is found in the month of May at N1 and the Lowest is in the month of September at N4.

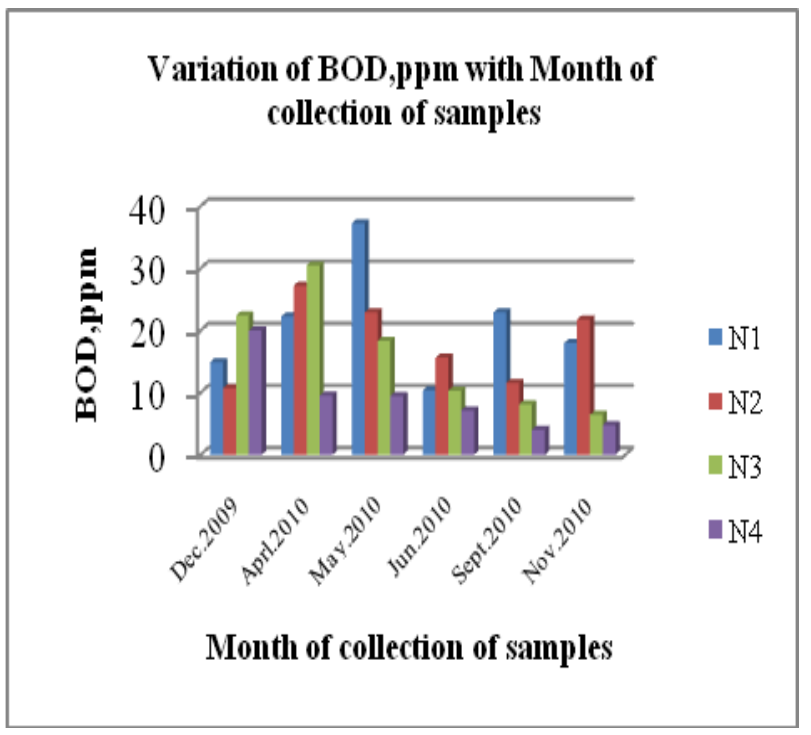

Fig- 2: Variation of BOD with month of sample collection

\subsection{Chloride}

The highest value of chloride is found in the month of September at N1 and the lowest value is atN4 in the month of November at N4. This value indicates the anthropogenic origin. 


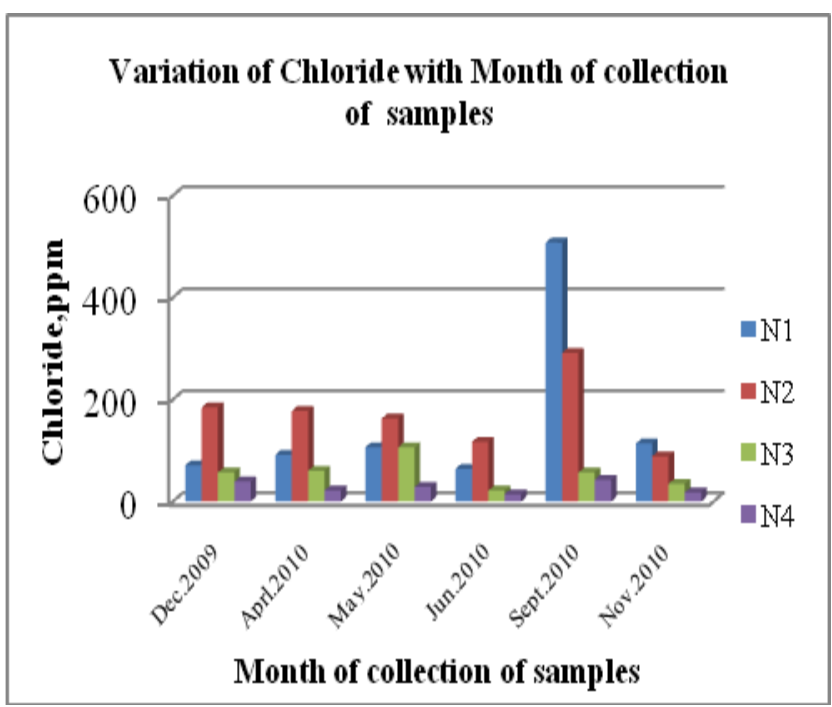

Fig-3: Variation of Chloride with month of sample collection

\subsection{Alkalinity}

Total alkalinity indicates the concentration of carbonates and bicarbonates in water Alkalinity value is found to be the lowest in the month of December (22ppm) and highest in the month of September (640ppm).

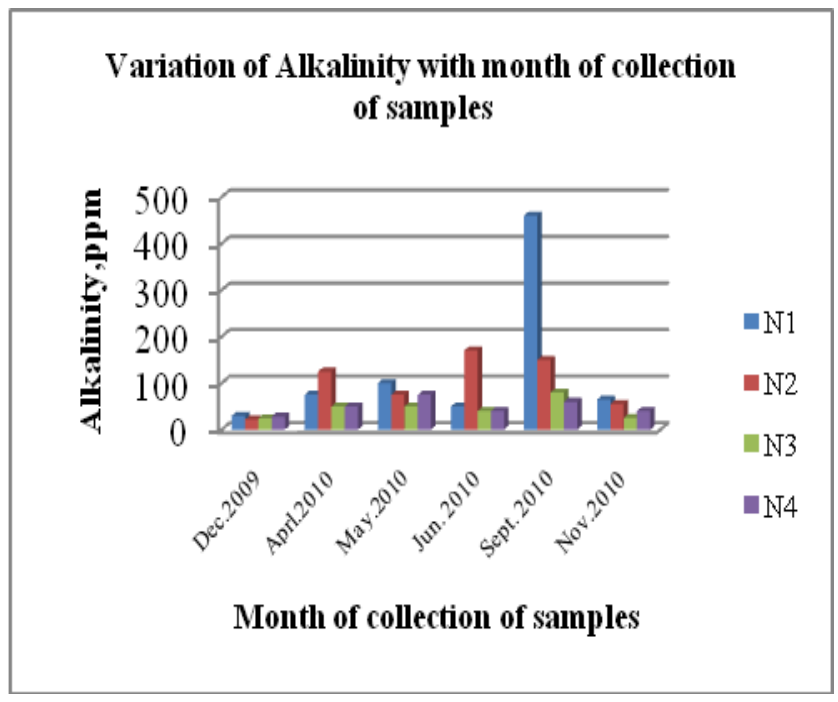

Fig- 4: Variation of Alkalinity with month of sample collection

\subsection{Total Hardness}

This water quality parameter is used to describe the effect of dissolved minerals (mostly $\mathrm{Ca}$ and $\mathrm{Mg}$ ) determining suitability of water quality for domestic, industrial and drinking purposes. Total hardness of sample ranged from 42- 420 $\mathrm{mg} / \mathrm{L}$. On the basis of total hardness [9], the samples can be classified as Soft $(0-70 \mathrm{mg} / \mathrm{L})$, moderately hard (75 -150 mg/l), Hard (150-300 mg/L), Very hard (above $300 \mathrm{mg} / \mathrm{L}$ ). It was observed that most of the samples were soft to hard.

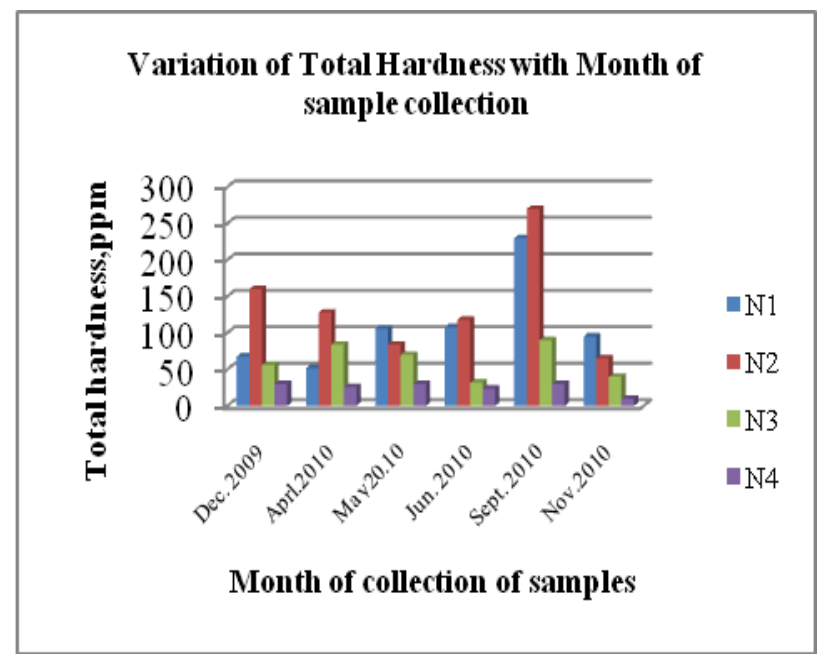

Fig- 5: Variation of Total hardness with month of sample collection

\subsection{Turbidity}

The turbidity values are in the range of 0.2 to $1.5 \mathrm{NTU}$, which are below the permisible limit. The heighest value recorded was in summer season as seen in figure 3.

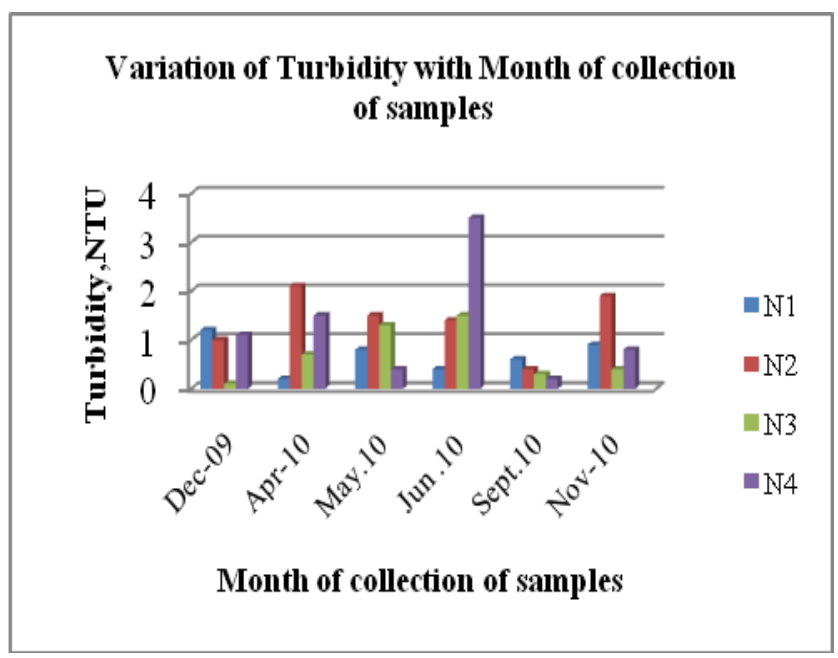

Fig-6: Variation of Turbidity with month of sample collection

\section{$3.7 \mathrm{pH}$}

The PH value is lowest in the month of September (6.68) and highest in the month of November (7.36). PH values are within the range of permissible limit of drinking water. 


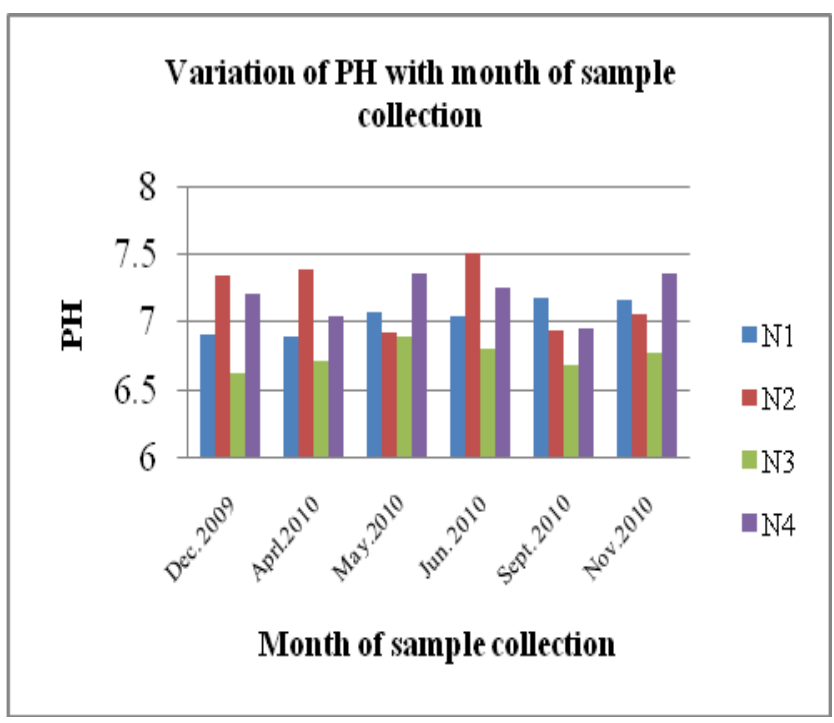

Fig -7: Variation of Turbidity with month of sample collection

\subsection{Water Quality Index:}

Water quality indices for major Indian rivers were reported and it was found that the WQI values were above 100 implying that the water of these rivers was not fit for human consumption without proper treatment [8].

In the present study, WQI for water samples, represented in figure 1, from Dhatav industrial area reveals the information regarding the status of water pollution. The value of WQI of N3 sample station in winter season and that of N4 sample station in summer season are below 100. The WQI values for remaining sampling stations are above 100 for monsoon, winter and summer seasons and were not fit for human use during the sampling period. The highest WQI for Nala N3 in monsoon season was 274 that indicate worst case of water pollution. Water quality Indices of Kundalika River in winter, summer \& monsoon seasons are shown in Table 2.

Table-3: Values of WQI for three seasons

\begin{tabular}{|l|l|l|l|l|}
\hline Seasons & $\mathrm{N} 1$ & $\mathrm{~N} 2$ & $\mathrm{~N} 3$ & $\mathrm{~N} 4$ \\
\hline Winter & 98.95 & 115.75 & 59.08 & 112.63 \\
\hline Summer & 104.21 & 103.72 & 106.49 & 88.71 \\
\hline monsoon & 694.46 & 152.35 & 274.31 & 204.97 \\
\hline
\end{tabular}

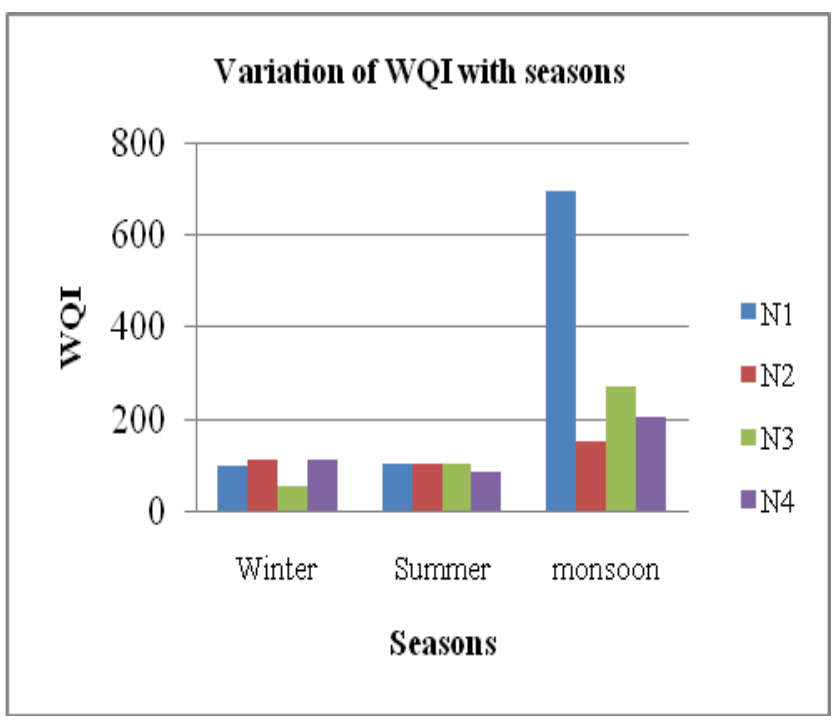

Fig.-8: Variation of WQI of samples with Seasons

\section{CONCLUSIONS}

The finding of present study of different physico-chemical parameters of water samples collected from Kundalika River and Nala from Dhatav industrial area, reveals that the WQI values of most of the sampling stations are above 100 . The total hardness value of $\mathrm{N} 1$ and $\mathrm{N} 2$ in summer season is higher than others. Turbidity values are within the acceptable range. The COD value for N1 is highest in rainy season. Therefore, quality of water is not suitable for human use.

\section{ACKNOWLEDGEMENTS}

The authors are thankful to Dr. Babasaheb Ambedkar Technological University, Lonere, Raigad (M.S.) for providing facility in the Department of Chemistry to complete work.

\section{REFERENCES}

[1]. APHA, Standard methods for examination of water and waste water, American Public Health Association, Washington, DC, 1992.

[2]. A Manual on Water and Wastewater Analysis, National Environmental Engineering Institute, Nehru Marg, Nagpur.

[3]. Tiwari T.N. and Manzur Ali, 'Water quality index for Indian Rivers' in a book on 'Ecology and Pollution of Indian Rivers'.

[4]. Goel P. K., Water Pollution- Causes, effects and Control, New Age International Publications.

[5]. Pimpale D. S., Pollution status of Taloja Industrial area, $\mathrm{Ph}$. D. Thesis, Mumbai University (2001).

[6]. Indira Gupta, Shivani Dhage and Rakesh Kumar, Study of variations in water quality of Mumbai coast through multivariate statistical analysis techniques, Indian Journal of Marine Sciences, Vol. 38 (2) 170-177 (2009). 
[7]. Khan, M. M., Admassu and H. R. Sharma, Suitability Assessment of Water Quality of river Shinta and its impact on the users: A case study from Gondar Town of Ethiopia, IJEP 29 (2), 137-144, (2009).

[8]. Tiwari T. N. and M. Mishra, A preliminary assignment of water quality index to major Indian rivers. Indian journal of Environmental Protection, 5 (4): 276-279, (1985).

[9]. A. D. Gawas, P. B. Lokhande and H. A. Mujawar, Study of physico- chemical parameters in Mahad Industrial Area. Poll Res., 25 (1), 109-114, (2006)

[10]. Rajan M. R. and I. Paneerselvam. (2005). Evaluation of drinking water quality in Dindigul city, Tamil Nadu Indian J. Environ and Ecoplan Vol. 10, No.3: 771-776.

[11]. Evaluation of surface water quality of Kanyakumari district through water quality assessment.International Journal of plant, animal and environmental sciences Vol. -4. Issue-1. Jan-Mar-2014

[12]. Nagendra Sharma, H.P. Sarma A study of ground water quality by evaluating water quality index from physicochemical parameters in Kamru metropolitian district, Assam. IJEP 29 (2) : 152-158 (2009).

[13]. Venkatasubramani, R., Meenambal, T., 2007. Study of sub-surface water quality in Mettupalayam Taluk of Coimbatore district Tamil Nadu, Nat. Environ Poll Tech., 6, $307-310$ 